\title{
Leptocephali of Anguilla japonica Found in the Waters South of the Okinawa Islands ${ }^{* 1}$
}

\author{
Osame TABETA*2 and Toru TAKAI*2 \\ (Received October 24, 1974)
}

\begin{abstract}
Fifty-two specimens of leptocephalus were collected in the waters south of the Okinawa Islands by the R/V Hakuho-maru, Ocean Research Institute, University of Tokyo, during November and December, 1973. These larvae are characterized by an olive leaf shape, a vent at three-fourths of total length (developing larva), straight intestine, 113-119 total myomeres, 6-13 ano-dorsal myomeres, major vertical blood vessels usually lying at segments 16,38 and 44, large pectoral fin, and no pigment except for the chorioid of the eye. The authors conclude that these larvae are those of Anguilla japonica T. et S., demonstrating that too much confidence should not be placed on the number of ano-dorsal myomeres in identifying anguillid leptocephali to the species level.
\end{abstract}

During November and December, 1973, the R/V Hakuho-maru, Ocean Research Institute, University of Tokyo, made the second research cruise for the biological study of larval stages of the Japanese eel in the Ryukyu Deep and adjacent waters ${ }^{11}$. In the course of this cruise, about 4,400 specimens of leptocephali were obtained at various depth from surface to about $1,000 \mathrm{~m}$ with the large larva net of $4 \mathrm{~m}$ diameter, standard fish larva net, and ORI net. As a result of a detailed study, 52 specimens of the total caught (49 in developing stage and 3 metamorphic stage) were positively identified as Anguilla japonica $\mathrm{T}$. et $\mathrm{S}$. on the basis of meristic characters and pigmentation. Leptocephali of the Japanese eel have been reported by MArsur et al. ${ }^{2,3)}$ from the waters south of Taiwan and the Ryukyu Deep. Recently, Yamamoto et al. ${ }^{4)}$ succeeded in insemination of $A$. japonica and made clear the morphological characters of spawned eggs and yolk-sac larvae. The authors give here a detailed description of the present larvae. The morphological changes through metamorphosis will be discussed in another paper.

\section{Materials and Methods}

The present specimens were obtained with a net of $4 \mathrm{~m}$ in mouth diameter and $12 \mathrm{~m}$ in length at night mainly in the surface layers. The catalogue number and the data of collections for each specimen are shown in Table 1. The nets were towed each time at a speed of 1.5 knots.

The specimens were examined alive on board by binocular microscope. They were measured after fixation in $10 \%$ neutralized formalin with borax following the methods adopted by JESPERSEN ${ }^{5)}$, CASTLE ${ }^{6)}$, and TABETA et al. ${ }^{7)}$

*1 Contribution from Shimonoseki University of Fisheries, No. 738.

*2 Department of Aquiculture \& Biology, Shimonoseki University of Fisheries, Yoshimi, Shimonoseki, Japan (多部田修・高井 微：水産大学校增殖学科) 


\section{Description}

1. Developing stage (Plate I, Figs. 1, 2)

Forty-nine specimens, $47.3-58.7 \mathrm{~mm}$ in total length (Table 1). The description given below is mainly based on a specimen of $57.9 \mathrm{~mm}$ in total length (Cat. ORI KH-73-5, No. 21-2). The other specimens were utilized to show the range of characters.

Measurements in mm: Total length 57.9 (47.3-58.7, mean 52.8), standard length $56.8(46.4-57.7,52.0)$, head $4.3(3.8-4.6,4.2)$, snout $1.1(1.0-1.1,1.0)$, eye $1.2(1.0-1.3$, 1.1), upper jaw $2.0(1.8-2.2,2.0)$, postorbital $2.2(1.8-2.4,2.1)$, pectoral $1.7(1.3-1.8,1.6)$, preanal 43.0 (35.5-43.1, 39.3), predorsal 38.1 (32.0-38.4, 35.1), ano-dorsal 4.9 (3.2-5.2, $4.2)$, depth just before eye $1.6(1.6-2.1,1.8)$, at pectoral base $3.5(3.1-3.8,3.4)$, at posterior margin of opisthonephros 9.3 (7.3-9.3, 8.6), at vent 9.0 (7.1-9.1, 8.4), maximum depth $10.0(8.0-10.0,9.0)$.

Branchiostegals not obvious. Total myomeres 115 (113-119, mean 116), predorsal $68(64-72,67)$, preanal $77(70-80,77)$, ano-dorsal $8(7-13,9)$. 1st vertical blood vessel at 16th myomere (14th-17th, 16th), 2nd at 39th (36-37th-40th, 38th), 3rd (last) at 45 th (42-43rd-46th, 44th) (Fig. 1). Anterior margin of gall-bladder at 26th myomere (24th-30th, 27th). Each fin obvious, dorsal rays 257 (235-266, 254.1), anal 213 (208-229, 217.0), pectoral $18(17-20,18)$, caudal $1+2+2+2+2+1=10 \quad(9-10,10)$. Teeth $\frac{1+1+\mathrm{V}+13}{1+1+\mathrm{X}+3}\left(\frac{1+1+\mathrm{V}-\mathrm{VII}+10-16}{1+1+\mathrm{VI}-\mathrm{XIII}+3-6}\right)$.

Body elongate, compressed, comparatively high, in the form of an olive leaf, with the greatest depth (a little less than one-fifth of the total length) at the midpoint of

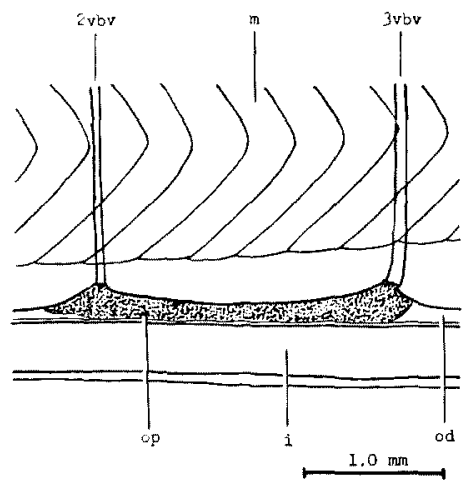

Fig. 1. Diagram showing the 2 nd and 3 rd (last) vertical blood vessels. $2 \mathrm{vbv}$, 2nd vertical blood vessel; $\mathrm{m}$, myomere; 3vbv, 3rd (last) vertical blood vessel; op, opisthonephros; i, intestine; od, opisthonephric duct. the body; tapering about equally in front of and behind this point. Head short, a little less than one-eleventh of total length, indented at the throat, with the dorsal profile slightly convex to make the head region clearly differentiated from the trunk. Snout short, one-fourth of head, pointed with slightly convex dorsal; nasal organ oval, anterior and posterior nostrils clearly separated; anterior nostril, more or less tube-like in form, at the midpoint between tip of snout and anterior margin of eye, not attached to the upper jaw; posterior nostril as a simple aperture located just before anterior margin of eye. In some younger specimens the anterior nostril is not tube-like. Eye moderate, a little more than one- 
Table 1. Collection data for leptocephali of Anguilla japonica

\begin{tabular}{|c|c|c|c|c|c|c|c|}
\hline \multirow[b]{2}{*}{ Cat. No. } & \multirow[b]{2}{*}{ Date } & \multirow[b]{2}{*}{ Time } & \multicolumn{2}{|c|}{ Locality } & \multicolumn{2}{|c|}{ Wire paid } & \multirow[b]{2}{*}{ Method } \\
\hline & & & $\begin{array}{l}\text { Lati- } \\
\text { tude } \\
\text { (N) }\end{array}$ & $\begin{array}{c}\text { Longi- } \\
\text { tude } \\
\text { (E) }\end{array}$ & $\begin{array}{c}\text { Length } \\
\text { (m) }\end{array}$ & $\begin{array}{c}\text { Angle } \\
\left(^{\circ}\right)\end{array}$ & \\
\hline \multicolumn{8}{|c|}{ ORI KH-73-5 (Ocean Research Institute, University of Tokyo) } \\
\hline No. $10-15-1 * 1,2$ & Nov. 27, 1973 & $18: 10-18: 40$ & $21-54.1$ & $128-46.2$ & 75 & 63 & $\mathbf{H}^{* 2}$ \\
\hline No. $10-18$ & - & $20: 14-20: 47$ & $21-55.3$ & $128-47.1$ & $150,75,30$ & 65 & $\mathrm{~S} * 3$ \\
\hline No. $10-23-1 \sim 3$ & - & $22: 10-22: 40$ & $21-56.8$ & $128-47.6$ & 75 & 72 & $\mathrm{H}$ \\
\hline No. $10-29 * 1$ & Nov. 28,1973 & $00: 45-01: 15$ & $21-57.9$ & $128-47.1$ & 75 & 53 & $\mathrm{H}$ \\
\hline No. $10-31-1^{* 1} \sim 4$ & - & $02: 05-02: 35$ & $21-53.3$ & $128-45.2$ & 75 & 73 & $\mathbf{H}$ \\
\hline No. B-1-1, 2 & Nov. 29,1973 & $18: 28-19: 04$ & $20-59.5$ & $129-59.9$ & $150,75,30$ & 62 & $\mathrm{~S}$ \\
\hline No. $11-5$ & Nov. 30,1973 & $19: 39-20: 09$ & $22-47.2$ & $128-19.0$ & 75 & 71 & $\mathrm{H}$ \\
\hline No. 11-6 & - & $20: 19-20: 49$ & $22-47.2$ & $128-19.3$ & 75 & 67 & $\mathrm{H}$ \\
\hline No. $11-10$ & - & $22: 55-23: 25$ & $22-48.9$ & $128-21.1$ & 40 & 63 & $\mathrm{H}$ \\
\hline No. $21-2$ & Dec. 2,1973 & $18: 11-18: 45$ & $21-56.2$ & $126-25.1$ & $150,75,35$ & 62 & $\mathrm{~S}$ \\
\hline No. $21-9-1 \sim 4$ & - & $21: 24-21: 54$ & $21-59.6$ & $126-26.0$ & 75 & 68 & $\mathrm{H}$ \\
\hline No. $21-10$ & - & $22: 03-22: 33$ & $22-00.5$ & $126-26.0$ & 75 & 72 & $\mathrm{H}$ \\
\hline No. $21-12-1 \sim 3$ & Dec. 3, 1973 & $00: 00-00: 30$ & $22-03.6$ & $126-27.9$ & 75 & 79 & $\mathrm{H}$ \\
\hline No. $21-13-1,2$ & - & $00: 41-01: 11$ & $22-05.3$ & $126-28.5$ & 75 & 67 & $\mathbf{H}$ \\
\hline No. $21-15-1 \sim 4$ & - & $01: 58-02: 28$ & $22-08.1$ & $126-29.3$ & 75 & 71 & $\mathrm{H}$ \\
\hline No. $21-16-1,2$ & - & $02: 38-03: 08$ & $22-06.9$ & $126-29.6$ & 75 & 70 & $\mathrm{H}$ \\
\hline No. C-8 & - & $19: 46-20: 16$ & $20-57.6$ & $126-23.3$ & 150 & 69 & $\mathrm{H}$ \\
\hline No. C-12 & - & $23: 08-23: 38$ & $20-56.0$ & $126-26.2$ & 150 & 69 & $\mathrm{H}$ \\
\hline No. C-16 & Dec. 4,1973 & $01: 09-01: 39$ & $20-54.6$ & $126-28.2$ & 75 & 71 & $\mathrm{H}$ \\
\hline No. C $-17-1,2$ & - & $01: 49-02: 19$ & $20-54.1$ & $126-28.6$ & 75 & 67 & $\mathrm{H}$ \\
\hline No. C-18 & - & $02: 31-03: 01$ & $20-53.0$ & $126-29.0$ & 150 & 67 & $\mathbf{H}$ \\
\hline No. D-3-1, 2 & - & $17: 58-18: 30$ & $22-01.9$ & $125-01.1$ & $150,75,35$ & 52 & $S$ \\
\hline No. D-4-1 4 & 一 & $18: 39-19: 09$ & $22-02.3$ & $125-01.5$ & 35 & - & $\mathbf{H}$ \\
\hline No. D-7 & - & $19: 17-19: 47$ & $22-02.9$ & $125-01.9$ & 35 & 72 & $\mathrm{H}$ \\
\hline No. D-9-1 3 & - & $20: 35-21: 05$ & $22-07.1$ & $125-01.8$ & 150 & 69 & $\mathrm{H}$ \\
\hline No. D-15 & Dec. 5,1973 & $00: 40-01: 10$ & $20-14.5$ & $125-05.9$ & 150 & 52 & $\mathbf{H}$ \\
\hline No. E-2 & - & $20: 09-20: 39$ & $23-36.5$ & $126-06.4$ & 75 & 72 & $\mathrm{H}$ \\
\hline No. E-5 & - & $22: 11-22: 41$ & $23-40.3$ & $126-09.1$ & 75 & 66 & $\mathbf{H}$ \\
\hline
\end{tabular}

*1 Metamorphic stage *2 Horizontal tow *3 Step tow

fourth of head, with its greatest diameter vertical; more than length of snout in horizontal diameter. Brain separated clearly into three parts in the posterodorsal region of eye: fore-, mid- and hind-brain. Jaws subequal; gape oblique, extending to level of posterior margin of pupil. Tongue developęd, its tip only free. Teeth conspicuous, very acute, 20 in upper jaw projecting outside those of lower jaw, distributed as follows: first tooth small and needle-like, directed immediately forwards and placed on the anterodorsal surface of the snout above the second tooth, which is much larger, downward-anteriorly directed gasping tooth; these two are followed by a second series of 5 large, needle-like fangs and a third of 13 much smaller teeth to a point below the posterior margin of pupil; in the lower jaw, the first tooth much larger, upward-anteriorly directed gasping tooth, and the second rather small, recurved tooth; these two are followed by the series of 10 fangs and 3 much smaller teeth, similar in grouping and size to those of upper jaw. 
Pectoral fin large, a little more than one-third of head, oval, base of fin fleshy with clear rays. Dorsal developed, rays obvious, its origin at two-thirds of total length, low anteriorly but higher posteriorly; Ca 90 rays before level of vent. Anal fin also developed, higher than dorsal, its origin at three-fourths of total length. Both fins connected posteriorly with caudal fin, forming the fan-like tail (Plate I, Figs. 1, 2). Caudal fin clearly differentiated from the dorsal and anal fins. The rays of pectoral fin and of the anterior part of dorsal and anal fins not countable in some younger specimens. Hypurals two.

The intestine is straight and not festooned or swollen, but makes a flexion at about 30th myomere (about one-third of total length); two tubercles (pyloric caeca ${ }^{8}$ ), projecting from the intestine just before the flexion. Liver extending from the level of about 10th myomere (about one-seventh of total length) to the flexed portion, covering the intestine. Gall-bladder located before the flexion; not clear from the left side, because of being covered by the liver tissue, but easily seen from the right side. The vent lies at about three-fourths of total length. The nerves from every segment ${ }^{93}$ arranged horizontally in the wide submarginal zones between the ends of the myomeres and the dorsal and ventral edges of the body and tail.

Color translucent both when alive and in preservative, with black pigment confined to the chorioid of the eye.

\section{Metamorphic stage (Plate I, Fig. 3)}

Three specimens, $53.1-60.2 \mathrm{~mm}$ in total length (Table 1). The description given below is mainly based on a specimen of $58.4 \mathrm{~mm}$ (Cat. ORI KH-73-5, No. 10-15-1). The other specimens were utilized to show the range of characters.

Measurements in $\mathrm{mm}$ : Total length 58.4 (53.1, 60.2), standard length 57.4 (52.1, $59.4)$, head $5.0(4.3,4.7)$, snout $1.0(0.9,1.0)$, eye $1.0(1.0,1.0)$, upper jaw $1.6(1.7,1.7)$, postorbital $3.0(2.5,2.6)$, pectoral $1.6(1.7,1.6)$, preanal $24.4(25.5,36.4)$, predorsal $20.8(22.2,33.0)$, ano-dorsal $3.6(3.4,3.4)$, depth just before eye $1.6(1.7,1.7)$, at pectoral base $3.5(3.5,3.6)$, at posterior margin of opisthonephros $9.1(7.8,8.5)$, maximum depth $9.1(7.8,8.7)$.

Branchiostegals not obvious. Total myomeres $115(117,117)$, predorsal $36(43,57)$, preanal $44(53,63)$, ano-dorsal $8(7,6)$. 1st vertical blood vessel at $14-15$ th myomere (15-16th, 17th), 2nd at 37th (38th, 37th), 3rd (last) at 43-44th (44th, 44th). Anterior margin of gall-bladder at 20th myomere (23rd, 28th). Each fin obvious, dorsal rays 270 $(-, 260)$, anal $226(232,225)$, pectoral $18(-, 19)$, caudal $1+2+2+2+2+1=10$ $(10,10)$. Teeth $\frac{0}{0}\left(\frac{0}{0}, \frac{0+0+0+0}{0+0+\mathbf{I}+0}\right)$. 
Body elongate, comparessed, not so deep (about one-seventh of total length), anterior part rather sub-cylindrical. The submarginal zones between the ends of myomeres and dorsal and ventral edges of the body and tail very narrow. Head relatively short, one-eleventh of total length, with gently sloping dorsal profile, indented at the throat, conspicuously differentiated from trunk. Snout short, about one-fifth of head, rounded, the dorsal profile slightly concave; nasal organ oval with a tubular anterior nostril protruding on the jaw at a little forward than midpoint between tip of snout and anterior margin of eye, and the posterior nostril as a simple aperture located just before the eye. Eye sub-circular, about one-fifth of head, subequal to snout length in horizontal diameter. Upper jaw shorter than lower jaw; gape oblique, reaching below middle of pupil. Brain separated clearly into three parts. Tongue well-developed, its tip and sides free. No larval teeth nor hollows except for the specimen of $60.2 \mathrm{~mm}$ in total length, which has I on left and II on right lower jaws. Branchiostegals developed but not countable in total number. Gill opening minute, locating at lower corner of pectoral base. Gills developed; 4 gill-arches recognizable externally. Pectoral long, one-third of head, pointed posteriorly. Dorsal low, its origin at one-third of total length, rays well developed; 45 rays before level of vent. Anal higher than dorsal, its origin at two-fifths of total length. A series of pterygiophores visible along the bases of both vertical fins. These vertical fins becoming higher posteriorly and connected to the caudal fin. Caudal fin clearly differentiated from dorsal and anal fins. Hypurals two, each separated again into two in the posterior parts.

The intestine is straight without any peculiar structure such as swellings. The flexion of intestine is located at about 23rd myomere (about one-fourth of total length); two elongate tubercles projecting just before this flexion, reaching $0.8 \mathrm{~mm}$ in length. Liver extending from the level of about 10th myomere (about one-seventh of total length) to the flexed portion, covering the intestine. Gall-bladder is located before the flexion and easily seen from the right side. The vent just behind opisthonephros; urinary bladder protruding posteriorly into the submarginal zone between the ends of myomeres and ventral edges of the tail, forming a blind sac. The nerves from each segment not obvious. Remarkable differences in positions of dorsal and anal origin, vent, flexion of intestine, etc., or number of larval teeth by specimens are caused by the difference in metamorphic stage, as will be mentioned later.

Color translucent both when alive and in preservative, with black pigment confined to the chorioid of the eye.

\section{Discussion}

The present specimens are characterized in having an olive leaf shape, a vent at three-fourths of total length (developing larvae), straight intestine, 113-119 total 
myomeres, 6-13 ano-dorsal myomeres, major vertical blood vessels usually lying at segments 16, 38 and 44, large pectoral fin, and no pigment except for the chorioid of the eye. These characters fit only the Anguillidae ${ }^{5,6,10,11)}$. Ege recognized 19 species and subspecies of eels around the world, of which the larvae of Anguilla marmorata, A. celebesensis, A. bicolor pacifica, and $A$. japonica may occur in this waters ${ }^{12)}$. Besides these 4 eels, we must take account of $A$. anguilla also in this discussion, because the elvers have been imported in large quantities and cultured in Japan and its neighbouring countries since 1968. Among them, the first 3 eels, having vertebral counts less than 111 , will probably be eliminated from the present specific discussion. It is said that the larva of $A$. anguilla are characterized by having pigmentation of the nerve-cord posteriorly in Stage II or semi-larva II, and more extensive nerve-cord pigmentation and cutaneous pigmentation at the extremity of the caudal fin in Stage III or semi-larva III of the metamorphic stage ${ }^{10,13,14}$. According to the number of teeth, and body shape or structure, the present developing larvae seem to be at full growth or thereabouts, and the metamorphic larvae correspond to Stage II (No. 10-29) and III (No. 10-15-1 and $10-31-1)$ of the metamorphic stage ${ }^{10,13)}$, or semi-larva II or III ${ }^{14}$ of $A$. anguilla. As described before, the present metamorphic larvae have no pigment except in the chorioid of the eye. The authors therefore identified them as Anguilla japonica. Numbers of rays in each fin also agree well with those in the elvers of this species. The present larvae bear no close resemblance to the yolk-sac larvae of the Japanese eel by YAMAmoto et al. ${ }^{4) *}$ The elvers of $A$. japonica described by TABETA et al. (in press) have 7-10 (mode 9) vertebrae in the ano-dorsal space, while the present larvae have 6-13 (9) myomeres, as mentioned above. This disagreement in number of ano-dorsal segments between the leptocephalus and elver stages seem to be generally observed in the

Table 2. Number of ano-dorsal segments of the eels in the leptocephalus and elver stages. The segments in the leptocephalus stage are counted from each text-figure

\begin{tabular}{ccc}
\hline Species & Leptocephalus (Samples) & Elver $^{* 1}$ (Samples) \\
\hline Long finned species & & \\
Anguilla anguilla $^{* 2}$ & $3-16(10)$ & $10-14(70)$ \\
Anguilla rostrata $^{* 2}$ & $3-9(6)$ & $6-9(11)$ \\
Anguilla marmorata $^{* 3}$ & $9,16(2)$ & $14-17(52)$ \\
Anguilla celebesensis*3 & $5,7(2)$ & $8-11(41)$ \\
Present species & $6-13(52)$ & $7-10(68)$ \\
Short finned species & & \\
Anguilla b. bicolor*3 & $0-7(9)$ & \\
*1 Tabeta (unpublished) & & \\
$*$ Schmidt (1909. 1916) & & \\
$* 3$ Jespersen (1942) & &
\end{tabular}

* The authors consider that most of so-called "anguillid leptocephalae" described by Matsui et al. ${ }^{31}$ must be re-examined in respect of sectional counts of myomeres. 
eels as shown in Table 2. The table shows as well that the long finned species can not be distinguished from the short finned species on the basis of number of ano-dorsal myomeres in the leptocephalus stage, because the range of segment number in the anodorsal space considerably overlaps in the long and short finned species. Too much confidence, therefore, must not be placed on the number of ano-dorsal myomeres in identifying the anguillid leptocephali to the species level.

\section{Acknowledgement}

The authors are deeply gratefull to Professor Masaharu NishrwaKi, Director of the Ocean Research Institute, University of Tokyo, and Professor Syoiti Tanaka, chief scientist of the cruise, for the invaluable opportunity to participate in the cruise and study the materials, all members of the co-operative work of Biological Study of Larval Stages of the Japanese Eel, and the officers and crew of the R/V Hakuho-maru, for their suggestions and help which were necessary in preparing this paper. The authors also express their sincere gratitude to Professor Kiichiro Yamamoto of Hokkaido University who allowed the authors to observe the spawned eggs and the yolk-sac larvae of the Japanese eel, Mr. Seirô KimurA of Kyushu University for preparing the photographs, Dr. Tetsushi Senta and Mr. Sen-min TAN of the Marine Fisheries Research Department, SEAFDEC, Singapore, for their advice in preparing this paper, and Dr. Isao MAtsul, President of the Shimonoseki University of Fisheries, for his suggestions, guidance and encouragement in identifying the present larvae. Dr. Peter J. H. CASTLE of the Victoria University of Wellington, New Zealand, kindly read and improved the manuscript.

\section{References}

1) S. TANAKA: This Bull., 41, 129 136 (1975).

2) I. Matsur, T. Takai and A. Kataoka: J. Shimonoseki Univ. Fish., 17, 17-23 (1968).

3) I. MATSUI and T. TAKAI: ibid., 20, 13-18 (1971).

4) K. Yamamoto, and K. Yamauchi: Nature, 251, 220-222 (1974).

5) P. JeSPERSEn: Dana-Rep., 22, 1-128 (1942).

6) P. H. J. Castle: Zool. Publ. Vict. Univ., N. Z., 23, 1-14 (1963).

7) O. Tabeta and T. TakaI: J. Shimonoseki Univ. Fish., 22, 49-53 (1973).

8) P. H. J. Castle: Zool. Africana, 3, 139-154 (1968).

9) E. Ford: J. Mar. Biol. Assoc., 17, 987-1000 (1931).

10) J. SCHMiDT: Medd. Komm. Hav. Fisk. 3, 1-17 (1909).

11) J. SCHMTDT: ibid. 5, 1-19 (1916).

12) V. EGE: Dana-Rep., 16, 1-256 (1939).

13) A. C. Strubberg: Medd. Komm. Hav. Fisk., 4, 1-11 (1913).

14) L. Bertin: Eels; A biological study, Cleaver-Hume Press, London, 1956, vi +192. 


\section{Explanation of Plate I}

Fig. 1. Leptocephalus in developing stage, Cat. ORI KH-73-5, No. 21-15-1, $48.4 \mathrm{~mm}$ in total length.

Fig. 2. Leptocephalus in developing stage, Cat. ORI KH-73-5, No. $21-2,57.9 \mathrm{~mm}$ in total length.

Fig. 3. Leptocephalus in metamorphic stage, Cat. ORI KH-73-5, No. 10-15-1, 58.4 mm in total length. 


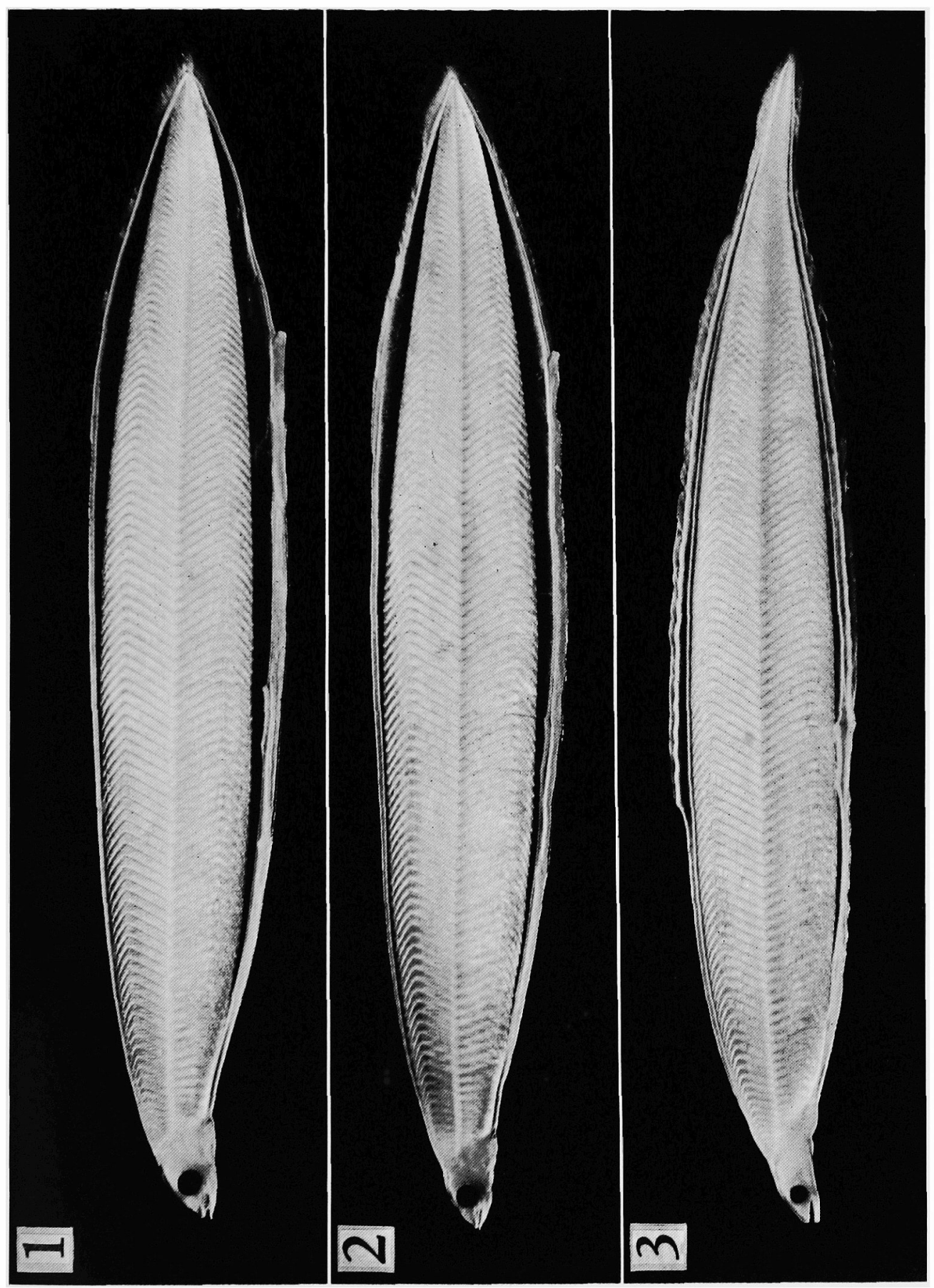

